http://dx.doi.org/10.4314/jae.v19i2.3

\title{
Perceived Contribution of Agricultural Transformation Agenda to Rice Production of Farm Families in Southwestern Nigeria
}

\author{
Kareem, H. T. \\ Department of Agricultural Extension and Rural Development \\ University of Ibadan \\ E-mail: abhakeem10@yahoo.com \\ Phone: 07063379638
}

\author{
Akinbile, L. A. \\ Department of Agricultural Extension and Rural Development \\ University of Ibadan \\ Email: lakinbile@yahoo.com \\ Phone: 08023250454
}

\begin{abstract}
The study examined the perceived contribution of the Agricultural Transformation Agenda ATA to rice production of farm families in Southwestern Nigeria. Interview schedule was used to collect data from 103 respondents in Ogun and Osun states. Data collected were described using percentages, mean, frequency distribution and analysed using Chi-square, Spearman Rho Rank correlation, Pearson Product Moment Correlation (PPMC) and Regression at $p=0.05$.Mean age of respondents was 46.9 years. Also, $54.4 \%$ of the respondents were male. More than half of the respondents (50.5\%) indicated that credit access as a factor affects their perception of the contribution of ATA to improving production. Also, 55.6\% had favourable perception of contribution of ATA to the improvement of their rice production. There was significant relationship between level of education $(r=0.240)$ and perception of the contribution of ATA to the improvement of rice production. Membership of farmers' association significantly affected respondents' perception of the contribution of ATA to the improvement of their rice production $(B=3.436)$. Farm families thus perceive that $A T A$ contribute greatly to the improvement of their rice production. Efforts at ensuring easier access to inputs, credit and adequate technical support through ATA would enhance participation.
\end{abstract}

Keyword: Perception of ATA, contribution of ATA, farm families.

\section{Introduction}

The Agricultural Transformation Agenda (ATA) was designed to achieve a hunger-free Nigeria through an agricultural sector that drives income growth, accelerates achievement of food and nutrition security, generates employment 
and transform Nigeria into a leading player in global food market to grow wealth for millions of farmers (FMARD, 2011).

According to Obiora and Emodi (2013), "ATA is all about enhancing capacity for agricultural commodity value chains leading to industrialization and employment creation, food security, infrastructure investments, private sector leadership, supportive fiscal policies and accessible market information systems to the farmers". It is aimed at a proactive change in the practice of agriculture and its perception in the country in several ways (Tiri, Ojoko and Aruwayo, 2014).

The ATA entails some components that include Growth Enhancement Scheme (GES), Nigerian Incentive-based Risk Sharing for Agricultural Lending (NIRSAL), transformation action plan for some priority agricultural commodities, commercialization of farms, National Farmers' Database, market corporation, Guarantee Minimum Price, mechanization support and repositioning of agricultural extension services.

Among the components, transformation action plan for some priority agricultural commodities which in summary comprises of transformation action plan for some crops, animals and their products and agricultural extension has very great significance because it has great relevance to the achievement of the goals of the Agricultural Transformation Agenda. According to AfDB (2013), the Agricultural Transformation Agenda (ATA) sets out to create over 3.5 million jobs along the value chain of rice, sorghum, cassava etc as priority crops for Nigeria teeming youths and women in particular. The rice transformation sub component is aimed to transform Nigeria from a nation that depends greatly on imported parboiled rice to a nation more dependent on locally produced parboiled rice. This is expected to be achieved by reducing demand for imported parboiled rice from 1.9M metric tons to $1.3 \mathrm{M}$ metric tons between 2011-2015, with a corresponding projected increase in demand for locally produced parboiled rice from 0M metric ton to $1.1 \mathrm{M}$ metric tons by 2015 (FMARD, 2011).

The purpose of the establishment of ATA which includes the growth of wealth for millions of farmers will be achieved if farm families as very important stakeholders perceived ATA to have significant contribution to the improvement of their farming activities. It is therefore necessary to confirm if the benefitting farm families involved in rice production perceive that ATA has significant contribution to their production.

The general objective of the study was to determine the perceived contribution of ATA to rice production of farm families in Southwestern Nigeria.

Specific objectives of the study are to:

i. describe the personal characteristics of the respondents in the study area; 
ii. identify the factors that affect respondents' perception of the contribution of Agricultural Transformation Agenda to their rice production

iii. determine respondents' perception of the impacts of the Agricultural Transformation Agenda on their rice production

The research hypotheses were:

$\mathrm{H}_{0} 1$ There is no significant relationship between respondents' personal characteristics and perception of the contribution of ATA to the rice production

\section{Methodology}

The study area is Southwestern, Nigeria which consist of Lagos, Ogun, Oyo, Osun, Ondo and Ekiti states. The population of the study is all farm families that cultivate rice on commercial basis in Southwestern Nigeria. They are those that cultivate rice on a commercial level.

Ogun state is made up of four administrative divisions which are Egba, Yewa, Remo and ljebu divisions while Osun state is divided into six administrative zones which are Iwo, Ife, Ikirun, Ilesa, Osogbo, and Ede zones. One division and and two zones were selected in Ogun and Osun states respectively. Egba division was selected out of the four divisions in Ogun State, while Ilesa and Iwo zones were selected out of the 6 zones in Osun State. At the second stage, Obafemi-Owode local government was selected out the 6 local government areas in Egba division while Oriade Local Government was selected out of the 6 local governments in llesa zone and Ola-Oluwa local government was selected out of those in Iwo zone. In Ogun state, Oba zone was selected from the 3 zones in Obafemi-Owode Local Government. Oba ward was selected from the 4 wards in Oba zone. Also, $10 \%$ of the 74 villages in Oba ward, that is, 7 villages which are, Kajola, Oluwo-Oke, Jaguna, Ayiwere, Oke-Ogbun, OkeEgan and Lemo were purposively selected. Snowballing was used to generate a list of rice farmers in Kajola, Oluwo-Oke, Jaguna, Ayiwere, Oke-Ogbun, OkeEgan and Lemo which resulted in 6, 14, 14, 20, 27, 25 and 6 rice farmers respectively. Sixty percent of the population of rice farmers in the 7 villages were selected. Therefore, 4, 8, 8, 12, 16, 15 and 4 rice farmers were selected in Kajola, Oluwo-Oke, Jaguna, Ayiwere, Oke-Ogbun, Oke-Egan and Lemo respectively for their intensity of rice production.

In Osun state, 3 villages which include Erin-ljesa, Erin-Oke, and Akola were purposively selected in Oriade local government while Onilapa Co-operative Farm was selected in Ola-Oluwa local government. Snowball sampling was used to generate the population of farmers in Erin-ljesa, Erin-Oke, and Akola in Oriade local government which are 12, 17 and 28 respectively. Also snowball sampling was used to generate the population rice farmers in Onilapa Cooperative Farm which was 4 rice farmers. 60 percent of the population of rice farmers in the 3 villages and Onilapa Co-operative Farm were selected, 
therefore, 7, 10, 17 and 2 rice farmers were selected respectively in Erin-ljesa, Erin-Oke, Akola and Onilapa Co-operative Farm respectively.

The data collected were analyzed using percentages, mean, frequency distribution while the hypotheses were analysed using Chi-square, Spearman rho rank correlation, Pearson's product moment correlation (PPMC) and Regression.

Dependent variable which is perception of the contribution of ATA was operationalized using a 5 point Likert-type scale of strongly agreed (SA), agreed $(A)$, disagreed (D) and strongly disagreed (SD).

\section{Results and Discussion}

\section{Personal characteristics of respondents}

Table 1 shows that the mean age of the members of farm families was 46.9 years. Members of farm families whose age fell between 46-84 years were $54.4 \%$. Those that fell between the age category of $46-58$ are agile adults $(35.9 \%)$ while the remaining (59-84 years) were aged adults $(18.5 \%)$. This implies that most of members of the farm families were agile. Therefore, it is expected that rice farming will be as efficient as expected due to the fact that agile adults were involved in rice production in the study area.

A large percentage of members of the farm families $(54.4 \%)$ were male. This suggests that male farmers were more involved in rice cultivation in the study area. Most of the members of the farm families $(82.5 \%)$ were married. Therefore it can be deduced that married members of farm families have potential to make significant contribution to rice production in the study area. Also, $53.4 \%$ of the farmers practice Islamic religion and $45.0 \%$ of them practice Christianity.

A sizeable number of the members of the farm families (47.6\%) had no formal education, which suggests that the effective use of ATA-based mobile phone for agricultural information sourcing most especially for the improvement of their rice production May be called to question. The finding is in line with that of Akinbile (2007) that $47.6 \%$ of respondents had no formal education. 
Table 1: Distribution of respondents based on their personal characteristics

\begin{tabular}{lll}
\hline Personal characteristics & Percentage $\mathbf{( n = 1 0 3 )}$ & Mean \\
\hline Age group & 16.5 & \\
$20-32$ & 29.1 & \\
$33-45$ & 35.9 & $46.9 \pm 13.16091$ \\
$46-58$ & 17.5 & \\
$59-71$ & 1.0 & \\
$72-84$ & & \\
Sex & 54.4 & \\
Male & 45.6 & \\
Female & & \\
Religion & 53.4 & \\
Islam & 43.7 \\
Christianity & 2.9 \\
Traditional & \\
Level of education & 47.6 \\
No formal education & 31.1 \\
Primary & 15.5 \\
Secondary & 5.8 \\
Tertiary & \\
Marital status & 6.8 \\
Single & 82.5 \\
Married & 10.7 \\
Widowed &
\end{tabular}

Source: Field survey (2014)

\section{Occupation of respondents}

Table 2 shows that the majority of the farm families (93.2\%) engaged in farming as their major occupation. This implies that respondents will readily participate in any rice transformation programme that they are favourably disposed towards. This is in line with the finding of Salau et al (2013) which showed that the majority $(86.0 \%)$ of the respondents were full time farmers. Also, $45.0 \%$ of the respondents had no minor occupation. Since the majority of the respondents have farming as their major occupation, it can be implied that any effort to transform farming practices that is perceived to be genuine will interest the respondents. 
Table 2: Distribution of respondents based on their occupation

\begin{tabular}{ll}
\hline Characteristics & Percentage $(\mathbf{n}=\mathbf{1 0 3})$ \\
\hline Major occupation & 93.2 \\
Farming & 3.9 \\
Trading & 1.0 \\
Fashion design & 1.0 \\
Panel fitting & 1.0 \\
Soothsaying & \\
Minor occupation & 45.6 \\
None & 4.9 \\
Farming & 18.4 \\
Trading & 9.7 \\
Crop processing & 4.9 \\
Motorcycle riding & 3.9 \\
Driving & 1.0 \\
Security & 11.7 \\
Artisanship &
\end{tabular}

\section{Factors affecting respondents' perception of the contribution of ATA to the improvement of their rice production}

Table 3 shows that the majority of the respondents indicated that level of awareness of ATA $(77.7 \%)$, income level $(85.4 \%)$, farm size $(86.4 \%)$ and hiring of labourers (83.5\%) were factors that affect their perception of the contribution of ATA to the improvement of their rice production. This implies that level of awareness of ATA, income level, farm size and hiring of labourers enhanced their favourable perception of the contribution of ATA to the improvement of their rice production while less than the majority of the respondents indicated that credit access (50.5\%) and level of benefits obtained from previous government agricultural programmes $(27.2 \%)$ as factors that affect their perception of the contribution of ATA to the improvement of their rice production. This implies that credit access and level of benefits obtained from previous government agricultural programmes enhanced favourable perception of less than the majority of the respondents on the contribution of ATA to the improvement of their rice production. 
Table 3: Factors affecting perception of the contribution of ATA to the improvement of rice production

\begin{tabular}{ll}
\hline Factors affecting perception & $\begin{array}{l}\text { Percentage indicating yes } \\
(\mathbf{n = 1 0 3 )}\end{array}$ \\
\hline Social factors & 40.8 \\
Cosmopoliteness & 26.2 \\
Level of children's education & 24.3 \\
Membership of farmers' association & 14.6 \\
Leadership position in the society & 77.7 \\
Level of awareness of ATA & \\
Economic factors & 85.4 \\
Income level & 50.5 \\
Credit access & 86.4 \\
Farm size & 83.5 \\
Hiring of labourers & 27.2 \\
Level of financial benefit obtained from & \\
previous government programmes & \\
Source: Field Survey (2014) &
\end{tabular}

\section{Perceived contribution of ATA to the improvement of rice production among respondents}

Table 4 shows that more than $60 \%$ of the respondents agreed to the following nine positively worded statements on perceived contribution of ATA to the improvement of their rice production; the use of ATA-based fertilizer via ewallet can lead to increase in yield (64.1\%), utilizing ATA-based improved crop varieties can enhance increase in quality of agricultural produce (61.2\%), GES of ATA can enhance better access to improved crop varieties for better production (64.1\%), NIRSAL can ensure increased income for farmers $(65 \%)$, utilizing ATA-based improved crop varieties is perceived to enhance access to better food by (64.1\%), utilizing GES can lead to acquisition of better means of transportation (64.1\%), ATA-based marketing system can lead to increased capability to carry out financial obligation on family members $(66 \%)$, ATA-based marketing system can lead to acquisition of assets that can be used as collateral for large scale production (65\%), Utilizing ATA-based mobile phone will enhance access to vital and useful (64.1\%).

Also, the table shows that more than $50 \%$ of the respondents disagreed with the following negatively worded statements on perceived impacts of the components of ATA on their crop production and standard of living; NIRSALbased loan cannot lead to better access to fund to procure improved varieties of crops when utilized (55.4\%), hiring of farm implement via e-wallet cannot enhance making cultivation easier, faster and more efficient (53.4\%), NIRSAL cannot lead to access to better health services (53.4\%), the use of GES cannot lead to access to better housing 
(55.3\%) and Hiring of ATA-based farm implement via e-wallet cannot encourage farmers to extend cultivation to uncultivated land portions (55.4\%).

Responses to the perception statements show that more than half of the respondents had favourable perception of the contribution of ATA to the improvement of their rice production. Therefore, it can be implied that a lot of the respondents will support the sustainability of ATA as a laudable means of ensuring the sustainability of the improvement of their farming activities.

The table also shows that more than half of the respondents (55.6\%) had favourable perception of the contribution of ATA to the improvement of their rice production.

\section{Table 4: Perception of the contribution of ATA to the improvement of rice production}

\begin{tabular}{|c|c|c|c|c|c|c|}
\hline \multirow[t]{2}{*}{ Perceived impacts } & \multicolumn{6}{|c|}{ Percentage $(n=103)$} \\
\hline & SA & A & $\mathrm{U}$ & $\mathrm{D}$ & S D & Mean \\
\hline The use of ATA-based fertilizer via e-wallet can lead to increase in yield & $\begin{array}{l}40 . \\
8\end{array}$ & $\begin{array}{l}23 . \\
3\end{array}$ & $\begin{array}{l}33 . \\
0\end{array}$ & 2.9 & 0.0 & 4.0194 \\
\hline $\begin{array}{l}\text { Utilizing ATA-based improved crop varieties can enhance increase in } \\
\text { quality of agricultural produce }\end{array}$ & $\begin{array}{l}37 . \\
9\end{array}$ & $\begin{array}{l}23 . \\
3\end{array}$ & $\begin{array}{l}31 . \\
1\end{array}$ & 2.9 & 4.9 & 3.8641 \\
\hline $\begin{array}{l}\text { NIRSAL-based loan cannot lead to better access to better access to fund } \\
\text { to procure improved varieties of crops when utilized }\end{array}$ & 3.9 & 1.0 & $\begin{array}{l}39 . \\
8\end{array}$ & $\begin{array}{l}24 . \\
3\end{array}$ & $\begin{array}{l}31 . \\
1\end{array}$ & 3.7767 \\
\hline $\begin{array}{l}\text { GES of ATA can enhance better access to improved crop varieties for } \\
\text { better production }\end{array}$ & $\begin{array}{l}42 . \\
7\end{array}$ & $\begin{array}{l}21 . \\
4\end{array}$ & $\begin{array}{l}32 . \\
0\end{array}$ & 2.9 & 1.0 & 4.0194 \\
\hline $\begin{array}{l}\text { Hiring of farm implement via e-wallet cannot enhance making cultivation } \\
\text { easier, faster and more efficient }\end{array}$ & 3.9 & 2.9 & $\begin{array}{l}39 . \\
8\end{array}$ & $\begin{array}{l}27 . \\
2\end{array}$ & $\begin{array}{l}26 . \\
2\end{array}$ & 3.6893 \\
\hline NIRSAL can ensure increased income for farmers & $\begin{array}{l}38 . \\
8\end{array}$ & $\begin{array}{l}26 . \\
2\end{array}$ & $\begin{array}{l}32 . \\
0\end{array}$ & 1.9 & 0.0 & 4.0294 \\
\hline $\begin{array}{l}\text { Utilizing ATA-based improved crop varieties can enhance access to better } \\
\text { food }\end{array}$ & $\begin{array}{l}37 . \\
9\end{array}$ & $\begin{array}{l}26 . \\
2\end{array}$ & $\begin{array}{l}33 . \\
0\end{array}$ & 1.0 & 1.0 & 4.0000 \\
\hline NIRSAL cannot lead to access to better health services & 2.9 & 2.9 & $\begin{array}{l}39 . \\
8\end{array}$ & $\begin{array}{l}24 . \\
3\end{array}$ & $\begin{array}{l}29 . \\
1\end{array}$ & 3.7451 \\
\hline Utilizing GES can lead to acquisition of better means of transportation & $\begin{array}{l}37 . \\
9\end{array}$ & $\begin{array}{l}26 . \\
2\end{array}$ & $\begin{array}{l}34 . \\
0\end{array}$ & 1.0 & 0.0 & 4.0196 \\
\hline $\begin{array}{l}\text { ATA-based marketing system can lead to increased capability to carry out } \\
\text { financial obligation on family members }\end{array}$ & $\begin{array}{l}39 . \\
8\end{array}$ & $\begin{array}{l}26 . \\
2\end{array}$ & $\begin{array}{l}33 . \\
0\end{array}$ & 1.0 & 0.0 & 4.0485 \\
\hline The use of GES cannot lead to access to better housing & 1.0 & 2.9 & $\begin{array}{l}39 . \\
8\end{array}$ & $\begin{array}{l}26 . \\
2\end{array}$ & $\begin{array}{l}29 . \\
1\end{array}$ & 3.8039 \\
\hline $\begin{array}{l}\text { ATA-based marketing system can lead to acquisition of assets that can be } \\
\text { used as collateral for large scale production }\end{array}$ & $\begin{array}{l}39 . \\
8\end{array}$ & $\begin{array}{l}25 . \\
2\end{array}$ & $\begin{array}{l}33 . \\
0\end{array}$ & 1.0 & 1.0 & 4.0194 \\
\hline $\begin{array}{l}\text { Hiring of ATA-based farm implement via e-wallet cannot encourage } \\
\text { farmers to extend cultivation to uncultivated land portions }\end{array}$ & 1.9 & 1.9 & $\begin{array}{l}40 . \\
8\end{array}$ & $\begin{array}{l}27 . \\
2\end{array}$ & $\begin{array}{l}28 . \\
2\end{array}$ & 3.7767 \\
\hline Utilizing ATA-based mobile phone will enhance access to vital and useful & $\begin{array}{l}39 . \\
8\end{array}$ & $\begin{array}{l}24 . \\
3\end{array}$ & $\begin{array}{l}33 . \\
0\end{array}$ & 1.0 & 1.9 & 3.9903 \\
\hline
\end{tabular}




\section{Relationship between respondents' personal characteristics and their perception of the contribution of ATA to the improvement of rice production}

Table 5 shows that there was no significant relationship between the following respondents' personal characteristics; sex, religion, marital status, major occupation, minor occupation and perception of the contribution of ATA to the improvement of their rice production. This implied that the above stated personal characteristics did not have meaningful effect on the respondents' perception of the contribution of ATA to the improvement of their rice production

Table 5: Relationship between respondents' personal characteristics and perception of the contribution of ATA to the improvement of rice production

\begin{tabular}{lll}
\hline Variables & $X^{2}$ & $\mathrm{df}$ \\
\hline Sex & $18.467^{*}$ & 14 \\
Religion & $32.984^{*}$ & 28 \\
Marital status & $22.938^{*}$ & 28 \\
Major occupation & $10.120^{*}$ & 56 \\
Minor occupation & $78.824^{*}$ & 98 \\
\hline
\end{tabular}

${ }^{\star} P \geq 0.05$

\section{Relationship between respondents' level of education, age and perception of the contribution of ATA to the improvement of rice production}

Respondents' level of education had significant relationship with their perception of the contribution of ATA to the improvement of their rice production. The implication of the relationship is that the more educated the respondents, the more favourable is their perception of the contribution of ATA to the improvement of their rice production. This correspond with the finding of Akudugu et al (2012) which intimated that the maximum level of education within the farm household was found to have a positive relationship with the probability of adoption. It is therefore necessary that education of farmers is encouraged to aid in their favourable perception of developmental programmes.

Respondents' age did not have significant relationship with their perception of the contribution of ATA to the improvement of their rice production. It can be implied that age is not a determinant of respondents' perception of the contribution of ATA to the improvement of their rice production. This is not in line with the finding of Gido et al (2013) which revealed that age of the household head positively influenced perception towards Organic Soil Management Practices (OSMP) 


\section{Factors affecting respondents' perception of the contribution of ATA to the improvement of rice}

Table 6 shows that there was significant contribution of membership of famers' association as a factor affecting respondents' perception of the contribution of ATA to the improvement of their rice production to perception of the contribution of ATA to the improvement of rice production. This implied that membership of famers' association as a factor affecting respondents' perception of the contribution of ATA to the improvement of their rice production had meaningful contribution in improving respondents' perception of the contribution of ATA to the improvement of their rice production

The $R$ square (0.146) indicates that the factors affecting respondents' perception of the contribution of ATA to the improvement of their rice production accounted for $14.6 \%$ variations in the respondents' perception of the contribution of ATA to the improvement of their rice production. This implies that the factors affecting perception of the contribution of ATA to the improvement of their rice production could explain $14.6 \%$ of the variation in respondents' perception of the contribution of ATA to the improvement of their rice production.

Furthermore, the table shows that there was no significant contribution of the factors affecting respondents' perception of the contribution of ATA to the improvement of their rice production to perception of the contribution of ATA to the improvement of rice production. This implied that most of the factors do not significantly contribute to the perception of the contribution of ATA to the improvement of rice production among respondents production.

Table 6: Regression of factors affecting respondents' perception of the contribution of ATA to the improvement of rice production

\begin{tabular}{|c|c|c|c|c|}
\hline Model & & \multirow[t]{2}{*}{$\begin{array}{l}\text { Standardized } \\
\text { Coefficients }\end{array}$} & \multirow{2}{*}{$\begin{array}{l}\mathbf{T} \\
15.359^{*}\end{array}$} & \multirow{2}{*}{$\begin{array}{c}\text { Sig. } \\
.000\end{array}$} \\
\hline & (Constant) & & & \\
\hline & factor on cosmopoliteness & .022 & .180 & .858 \\
\hline & factor on level of child education & -.082 & -.719 & .474 \\
\hline & factor on membership of farmers' association & .396 & $3.436^{*}$ & .001 \\
\hline & factor on leadership position in the society & .029 & .271 & .787 \\
\hline & factor on level of awareness of ata & -.020 & -.151 & .880 \\
\hline & factor on income level & -.043 & -.238 & .812 \\
\hline & factor on credit access & .043 & .363 & .718 \\
\hline & factor on farm size & .018 & .112 & .911 \\
\hline & factor on hiring labour & .026 & .183 & .855 \\
\hline & factor on level of benefit from govt agric prog & -.230 & -1.907 & .060 \\
\hline
\end{tabular}

${ }^{*} P \leq 0.05$. Adjusted $R$ square $=0.049 ;$ Std. Error of the Estimate $=11.37770$,

$F=1.508, p=0.150$. 


\section{Conclusion}

Larger number of the farm families perceived that ATA had great contribution to the improvement of their rice production; therefore, a lot of the members of farm families will support the sustainability of ATA. Level of education is a great factor that influences the perception of the contribution of ATA to the improvement of rice production in the study area. Credit access as an economic factor was recognized by many of the farm families as factor that enhanced their favourable perception of the contribution of ATA to the improvement of their rice production.

\section{Recommendations}

This study recommends the following;

- Efforts such as ensuring easier access to farm inputs and adequate technical support through ATA should be made by all concerned stakeholders in order for the farm families to concretely realize the expected impacts of ATA

- $\quad$ ATA should be redesigned for adequate and easier participation such as better support and short term mandate for extension to determine reasons that made substantial number of farm family members to have unfavourable perception about the contribution of ATA in improving their farming activities in order to provide lasting solutions.

- Youth should be encouraged to venture into ATA rice programme so as to ensure sustainability of laudable ATA.

- NIRSAL should be made very accessible to rice farmers, and unnecessary bureaucracy and high-cost-collateral should be avoided in order to solve perpetual problem of lack of adequate access to credit.

\section{References}

African development Bank (AfDB) (2013). Strategic Environmental and Social Assessment of Agricultural Transformation Agenda Support Programme PHASE 1 in Nigeria [Executive Summary]. Retrieved from www.google.com $/ \mathrm{m}$ ?q=environmental+and+socia+assessment+of+agric ulturl-transformation+agenda+support+programmephase $+1+$ by+african +develop ent+bank+group\&client

Akinbile, L. A. (2007). Determinants of productivity level among rice farmers in Ogun state. African Crop Science Conference Proceedings. Vol. 8: pp 1339-1344. 
Akudugu, M. A. Guo, E and Dadzie, S. K (2012).Adoption of Modern Agricultural Production Technologies by Farm Households in Ghana: What Factors Influence their Decisions? Journal of Biology, Agriculture and Healthcare. Vol 2, No.3, 2012

Federal Ministry of Agriculture and Rural development, (FMARD) (2011). Agricultural Transformation Agenda: We will grow Nigeria's agricultural sector. Retrieved from unaab.edu.ng/attachments/Agricultural Transform-ation Blue Print.pdf

Gido, O. E. Job, K. L. Gicuru, K. I. Benjamin, K. M. Sibiko, W. K. and Mwangi, K. J. (2013). Maize Farmers Perceptions towards Organic Soil Management Practices in Bungoma County, Kenya. Research Journal of Environmental and Earth Sciences. 5(2): 41-48, 2013

Iwuchukwu, J. C. and Igbokwe, E. M. (2012). Lessons from agricultural policies and programmes in Nigeria. Journal of Law, Policy and Globalization, vol.5: Retrieved from www.iiste.org/Journals/index.php/JLPG/article/download/2334/2335

Maboja, W (2014). A closer look at Nigeria's GDP rebasing. [CNBCAFRICA.com]. Retrieved from cnbcafrica.com/news/westernafrica/2014/04/11/a-closer-look-a-nigerias-gdp-rebasing National Bureau of Statistics (NBS) (2012). Agriculture. Retrieved from nigerianstat.gov.ng/sectorstat/sectors/Agriculture

Obiora C. J. and Emodi, A. I. (2013). Restructuring the Agricultural Extension Service for Effective Agricultural Transformation Agenda in Nigeria. Greener Journal Agricultural Sciences, vol. 3(6): pp. 516-522.

Ogunsumi, L. O., Ajayi, A., Amire, C. M. and Williams, S (2013). Sustainability of Agricultural Transformation Agenda: The Place of Rice Farmers in Ogun State, Nigeria. Research on Humanities and Social Sciences. Vol 3, No.13: 2013.

Salau, E.S. Saingbe, N. D. and Garba, M. N. :(2013). Agricultural information needs of small holder farmers in central agricultural zone of Nasarawa state. Journal of Agricultural Extension. Vol.17 (2): December, 2013. http://dx.doi.org/10.4314/jae.v17i2.15

Tiri, G. D., Ojoko, E. A and Aruwayo, A. (2014). Growth Enhancement Support Scheme (GESS) and the challenges of food security in Nigeria: a review. ARPN Journal of Agricultural and Biological Science. VOL. 9, NO. 7: July 2014. 